\title{
Factors of the Lectin Pathway of Complement Activation and Their Clinical Associations in Neonates
}

\author{
Maciej Cedzynski, ${ }^{1}$ Anna St. Swierzko, ${ }^{1}$ and David C. Kilpatrick ${ }^{2}$ \\ ${ }^{1}$ Laboratory of Immunobiology of Infections, Institute of Medical Biology, Polish Academy of Sciences, Lodowa 106, \\ 93-232 Lodz, Poland \\ ${ }^{2}$ National Science Laboratory, Scottish National Blood Transfusion Service, Ellen's Glen Road, Edinburgh EH17 7QT, Scotland, UK \\ Correspondence should be addressed to Maciej Cedzynski, mcedzynski@cbm.pan.pl
}

Received 15 September 2011; Revised 12 December 2011; Accepted 30 December 2011

Academic Editor: Misao Matsushita

Copyright (๑) 2012 Maciej Cedzynski et al. This is an open access article distributed under the Creative Commons Attribution License, which permits unrestricted use, distribution, and reproduction in any medium, provided the original work is properly cited.

\begin{abstract}
This paper summarizes the data concerning soluble defense lectins (mannan-binding lectin, M-ficolin, L-ficolin, and H-ficolin) with the unique ability to activate complement and their associated serine proteases (MASPs) in neonates. The clinical importance of deficiencies of these immune factors is presented in aspects of perinatal mortality, premature births, and low birthweight. Prenatal serum concentrations of L-ficolin, H-ficolin, and MASP-2 (and probably M-ficolin) correlate with gestational age and birthweight. The relationship of serum MBL to gestational age is controversial. The MBL2 genotypes XA/O and O/O (associated with low-serum MBL) are associated with perinatal infections, whereas the high serum MBL-conferring A/A genotypes may be associated with prematurity. Low-serum L-ficolin concentrations, but not low-serum H-ficolin concentrations, are also associated with perinatal infections. Much of the literature is inconsistent, and the relationships reported so far require independent confirmation at both gene and protein levels. Our preliminary conclusion is that these soluble defense lectins play a protective role in the neonate, and that insufficiency of such factors contributes to the adverse consequences of prematurity and low birthweight.
\end{abstract}

\section{Underdevelopment of the Neonatal Immune System}

Newborns have to adapt to their postnatal environment. They are exposed to extrauterine conditions which are completely different from intrauterine conditions. During the neonatal period, the most dramatic and rapid physiological changes in human life take place. Innate immune mechanisms are particularly important at that time. The high susceptibility of newborns to infection results from the immaturity of the immune system, despite immunoglobulins obtained via the placenta or breast feeding. Innate immunity plays an especially important role when the repertoire of maternal IgG does not include specific antibodies for the infecting agent or when, due to premature delivery, immunoglobulins do not achieve a sufficient level in the infant's circulation [1-3]. The neonatal inflammatory response is, however, impaired not only due to deficient antigen-specific $\mathrm{T}$ and $\mathrm{B}$ lymphocyte functions (reflecting the lack of exposure to microbial agents) but also due to low activity of neutrophils, complement activity, production of cytokines and fibronectin. The poor response of neonates to T-independent polysaccharide antigens significantly increases susceptibility to bacterial infections $[1,2,4]$. Low ability to produce specific antibodies to such components, often exposed on the microbial cell surface, may suggest an important role for serum defense lectins in the first period of life. However, the opsonic and bactericidal activity of neonatal serum is not fully effective since the concentrations and activities of complement factors in babies are lower than those in adults [5]. Structures of such important organs as bone marrow, spleen, or lymph nodes are not fully developed $[1,2]$.

\section{The Lectin Pathway of Complement Activation}

The complement system is a crucial mediator of the immune response, interacting with other innate as well as acquired 
immunity mechanisms. It contributes significantly to cell homeostasis, tissue development and repair, reproduction and crosstalk with other endogenous cascades, like the coagulation network [6-10].

Each of three major complement activation pathways (classical, CP; alternative, AP; lectin, LP) employs its specific recognition molecules and initiating serine proteases (Figure 1). Until recently, it was believed that only one collectin (mannan-binding lectin, MBL) and three ficolins: M- (-1), L- (-2), and H- (-3) were capable of activating LP. However, it now seems the novel or non-classical collectin, CL-11 (collectin-11, known also as collectin kidney-1 or CL$\mathrm{K} 1)$ also has this property [12].

The lectin pathway of complement activation is initiated upon binding of collectin- or ficolin-MASP complex to target structures. Three MBL-associated serine proteases (MASP-1, MASP-2, and MASP-3) and two nonenzymatic proteins MAp19 (sMAP) and MAp44 (MAP-1) have been described. MASP-2 and MAp19 are products of alternative splicing of the MASP2 gene. Similarly, synthesis of MASP-1, -3 and MAp44 is under control of a single MASP1/3 gene [13-18]. MASP-2 is believed to be the key enzyme, responsible for LP activation while other proteins of the MASP family play up- or downregulatory roles [19-24]. MASP-2 cleaves C4, releasing $\mathrm{C} 4 \mathrm{a}$ and $\mathrm{C} 4 \mathrm{~b}$ fragments. In the $\mathrm{C} 4 \mathrm{~b}$ molecule, a thioester group is exposed. It may bind to hydroxyl or amide groups on the microbial surface. Next, in the process of C2 cleavage, the $\mathrm{C} 2 \mathrm{~b}$ fragment is released, while $\mathrm{C} 2 \mathrm{a}$ remains bound to C4b. The C4bC2a complex is the C3 convertase that activates $\mathrm{C} 3$, resulting in liberation of $\mathrm{C} 3 \mathrm{a}$ and covalent binding of $\mathrm{C} 3 \mathrm{~b}$ to the microbial surface via a thioester group. The coating of microorganisms with $\mathrm{C} 4 \mathrm{~b}$ or $\mathrm{C} 3 \mathrm{~b}$ opsonins facilitates phagocytosis. The $\mathrm{C} 4 \mathrm{~b} 2 \mathrm{a} 3 \mathrm{~b}$ is a $\mathrm{C} 5$ convertase that cleaves the C5 component. The C5a fragment is released, while C5b may bind other C' cascade factors (common pathway), which allows the membrane attack complex (MAC, C5b-9) to form and, in consequence, to lyse the microbial cell. The liberated C4a, C3a, and C5a act as anaphylatoxins attracting phagocytic cells $[13,25]$. Moreover, MASP are believed to participate in the coagulation cascade activation [21, 26-29].

\section{Selected Factors of Complement Lectin Pathway Activation in Neonates}

In general, serum levels of mannan-binding lectin, ficolins, and MASP-2 are lower in neonates than in older children, teenagers or adults. They moreover often positively correlate with gestational age and birthweight [30-32]. Average cord sera concentrations/activities of these factors are presented in Table 1 while their clinical associations are summarised in Table 2 .

3.1. Mannan-Binding Lectin. Mannan-binding lectin (mannose-binding lectin), like other collectins, possesses both a collagen-like triple helical region and a C-type carbohydrate recognition domain. It is a pattern-recognition molecule
TABle 1: Average (median, mean) concentrations or activities of selected complement lectin pathway factors (based on own investigation).

\begin{tabular}{lcccc}
\hline & \multicolumn{5}{c}{ Concentration/activity } & \multirow{2}{*}{ References } \\
& 1124 & 1213 & $0-5895$ & {$[30,35]$} \\
\hline MBL $(\mathrm{ng} / \mathrm{mL})$ & 93 & 118 & $0-812$ & {$[31]$} \\
MASP-2 (ng/mL) & 272 & 366 & $0-4112$ & {$[30,35]$} \\
MBL-MASP-2 (LP) $(\mathrm{mU} / \mathrm{mL})$ & 2500 & 2540 & $100-5700$ & {$[30]$} \\
L-ficolin $(\mathrm{ng} / \mathrm{mL})$ & 14600 & 15300 & $0-56500$ & {$[36]$} \\
H-ficolin $(\mathrm{ng} / \mathrm{mL})$ & & & & \\
\hline
\end{tabular}

(PRM), binding with a high affinity to microbial polysaccharides or glycoconjugates rich in D-mannose, N-acetyl-Dglucosamine, or L-fucose. MBL insufficiency is believed to be the most common human immunodeficiency, having numerous clinical associations $[15,33,34]$.

Single-nucleotide polymorphisms (SNPs) in exon 1 of the MBL2 gene are responsible for altered MBL serum levels and impaired function. Individuals with the A/A wild-type genotype generally have high $\mathrm{MBL}$ serum concentrations, whereas individuals with the $\mathrm{A} / \mathrm{O}$ and particularly the $\mathrm{O} / \mathrm{O}$ genotypes (where $\mathrm{O}$ is the collective designation of the mutant dominant alleles $\mathrm{D}, \mathrm{B}$, and $\mathrm{C}$ corresponding to mutations in codons 52, 54, and 57, respectively) show lower MBL serum concentrations. Polymorphisms in the promoter and the untranslated region of exon $1(\mathrm{H} / \mathrm{L}, \mathrm{Y} / \mathrm{X}$, and P/Q at positions $-550,-221$, and +4 , respectively) influence the gene expression level and thus the serum protein concentration $[37,38]$. O/O homo- or heterozygotes as well as LXPA/O heterozygotes are considered to be MBL deficient.

A correlation between MBL concentrations and gestational age has been reported by Lau et al. [39], Kielgast et al. [40], Hilgendorff et al. [41], and Sallenbach et al. [32]. However, Swierzko et al. [30, 35], in by far the largest series reported of full MBL2 genotypes, MBL cord serum levels and MBL-dependent lectin pathway activities, did not find such a relationship. Bodamer et al. [42] suggested an association of $\mathrm{D} M B L 2$ gene variant as well as $\mathrm{O} / \mathrm{O}$ genotypes in general with prematurity. In contrast, Frakking et al. [43] found no difference in the distribution of genotypes between premature and term neonates, while Swierzko et al. [30] demonstrated high-serum MBL-conferring A/A genotypes to be more frequent among premature babies. Similarly, the role of maternal genotype still remains unclear. Annells et al. [44] postulated that codon 54 (B) variants in mothers contribute to the shortened gestational age. Van de Geijn et al. [45], however showed women carrying no exon 1 mutation to be liable to suffer a preterm delivery. Thus, it remains to be elucidated whether MBL-insufficient genotypes (via enhancing the susceptibility to intrauterine infections) or high-MBLassociated gene variants (via participation in inflammatory processes) contribute to the shortening of pregnancy. Both possibilities seem to be reasonable, depending on interplay with other endogenous and environmental factors.

Numerous studies address the influence of MBL deficiency on perinatal morbidity and mortality from serious 


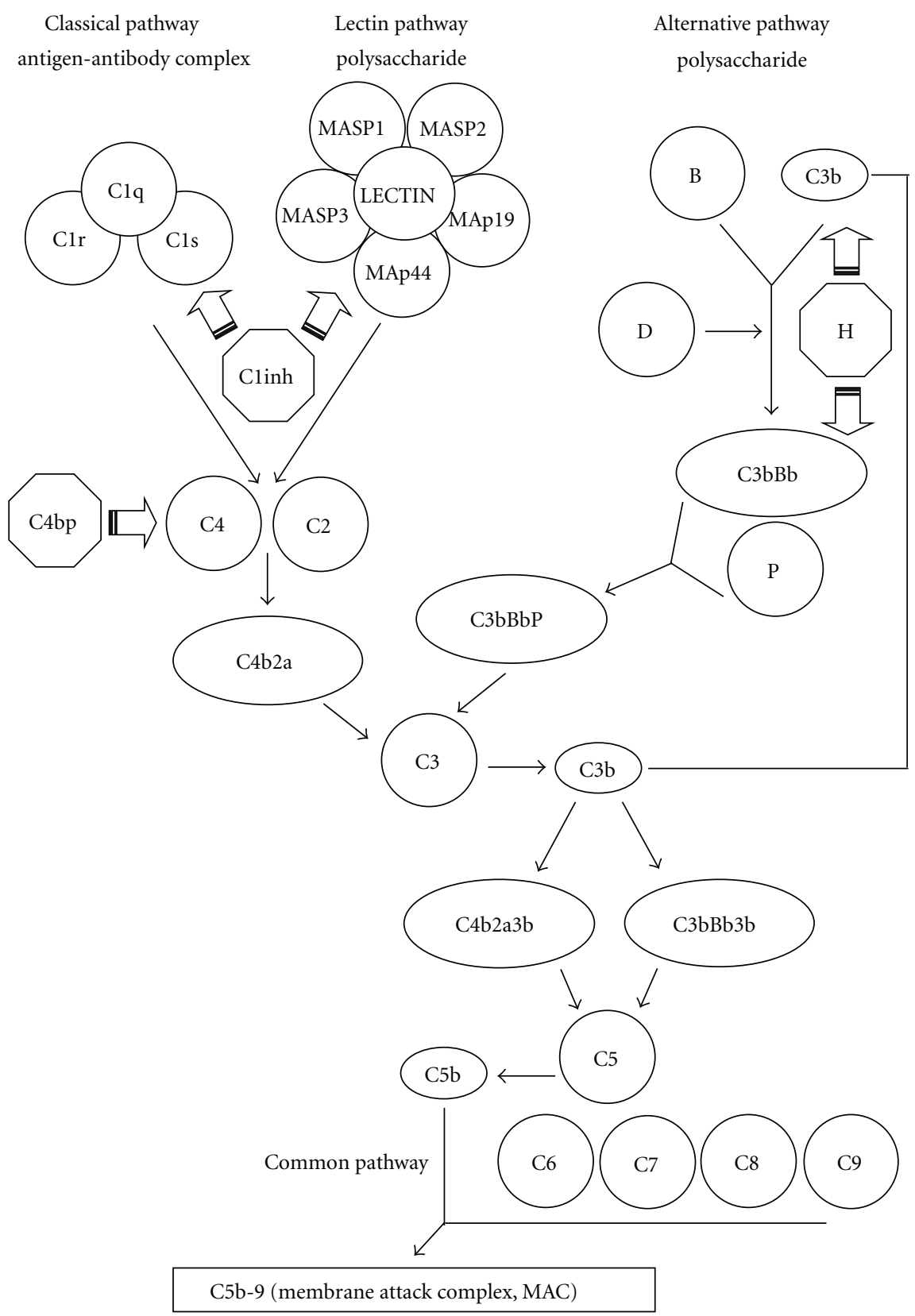

FIGURE 1: The three major pathways of complement activation. These pathways differ crucially in their initiating events: the classical pathway depends on antibody recognition and binding to $\mathrm{C} 1 \mathrm{q}$; the alternative pathway depends on low-level spontaneous hydrolysis of $\mathrm{C} 3$ being stabilised by bacterial polysaccharides and so forth; and the lectin pathway depends on the recognition of saccharides by ficolins and certain collectins (MBL, CL-11). The common end result is the generation of C3a and C3b from C3; the classical and lectin pathways produce C4b2a as the $\mathrm{C} 3$ convertase, whereas that role is played by $\mathrm{C} 3 \mathrm{bBb}$ in the alternative pathway. $\mathrm{C} 1$ inhibitor (C1inh) and C4-binding protein (C4bp) are downregulators of both classical and lectin pathways; $\mathrm{H}$ factor is an inhibitor of the early phase of alternative pathway, modified from $[11]$.

infections such as sepsis or pneumonia, especially in premature infants [46-53]. Schlapbach et al. [54] suggested that low MBL concentrations are a risk factor for sepsis associated with infections with Gram-positive but not Gram-negative bacteria. Moreover, Wahab Mohamed and Saeed [52] found MBL deficiency to predict development of septic shock. Swierzko et al. [30] found a higher incidence of perinatal infections in general among babies having the MBL deficiency-associated genotypes (LXPA/O and O/O) and a higher frequency of the $\mathrm{D}$ variant (codon 52 mutation) among neonates with infections. Two MBL2 gene haplotypes, LYPA and HYPD, were suggested to increase a risk of childhood neurological disorder, cerebral palsy, after perinatal exposure to certain viruses (enteroviruses, herpes simplex viruses 1 and 2, Epstein-Barr virus, cytomegalovirus, varicellazoster virus, and human herpesviruses $6,7,8)[55]$. 
TABLE 2: Some clinical associations of selected complement lectin pathway factors, based on own investigation.

\begin{tabular}{|c|c|c|c|c|c|}
\hline \multirow{2}{*}{ LP factor } & \multirow{2}{*}{ Parameter } & \multicolumn{3}{|c|}{ Clinical associations } & \multirow{2}{*}{ Reference } \\
\hline & & $\begin{array}{l}\text { Perinatal } \\
\text { infections }\end{array}$ & $\begin{array}{l}\text { Preterm/premature } \\
\text { births }{ }^{1}\end{array}$ & $\begin{array}{l}\text { Low birth } \\
\text { weight }^{2}\end{array}$ & \\
\hline \multirow[t]{2}{*}{ MBL } & $\begin{array}{l}\text { Low cord serum } \\
\text { concentration } \\
(<150 \mathrm{ng} / \mathrm{mL})\end{array}$ & no & no & no & {$[30]$} \\
\hline & $\begin{array}{c}\text { Genotype (promoter \& } \\
\text { exon } 1 \text { ) }\end{array}$ & $\mathrm{XA} / \mathrm{O}$ and $\mathrm{O} / \mathrm{O}$ & A/A (prematurity) & no & \\
\hline \multirow[t]{2}{*}{ MASP-2 } & $\begin{array}{l}\text { Low cord serum } \\
\text { concentration } \\
(<42 \mathrm{ng} / \mathrm{mL})\end{array}$ & no & yes & yes & {$[31]$} \\
\hline & $\begin{array}{l}\text { Genotype (D120G } \\
\text { dimorphism) }\end{array}$ & no & no & no & \\
\hline $\begin{array}{l}\text { MBL-MASP-2 } \\
\text { complex activity }\end{array}$ & $\begin{array}{l}\text { Low cord serum activity } \\
\qquad(<60 \mathrm{mU} / \mathrm{mL})\end{array}$ & no & yes & no & {$[30]$} \\
\hline L-ficolin & $\begin{array}{l}\text { Low cord serum } \\
\text { concentrations } \\
(<1 \mu \mathrm{g} / \mathrm{mL})\end{array}$ & yes & yes & yes & {$[30]$} \\
\hline \multirow[t]{2}{*}{ H-ficolin } & $\begin{array}{l}\text { Low cord serum } \\
\text { concentrations } \\
(<8.6 \mu \mathrm{g} / \mathrm{mL})\end{array}$ & no & yes & yes & {$[36]$} \\
\hline & $\begin{array}{l}\text { Genotype (1637delC } \\
\text { frameshift mutation) }\end{array}$ & no & no & no & \\
\hline
\end{tabular}

${ }^{1}$ Preterm births: gestational age $\leq 37$ weeks; premature births: gestational age $\leq 35$ weeks.

${ }^{2}$ Low birthweight: $<2500 \mathrm{~g}$.

On the other hand, several reports demonstrated no association of mannan-binding lectin deficiency with neonatal sepsis or viral infections. It however may reflect the specificity of aethiological agents or the group studied: nosocomial fungal invasive infections in preterm babies [56], sepsis caused by coagulase-negative staphylococci in a similar group [57], sepsis in very low birthweight babies [58], and pre- or perinatal infections with cytomegalovirus [59].

The MBL2 gene B variant was shown to enhance susceptibility to such inflammatory disorders as bronchopulmonary dy-splasia (BPD) and intraventricular haemorrhage (IVH) $[53,60]$. In contrast, Capoluongo et al. [61] found low MBLassociated genotypes to be linked to a better outcome in BPD, while Koroglu et al. [50] did not observe an influence of MBL2 polymorphism on incidence of bronchopulmonary dysplasia, intraventricular haemorrhage, respiratory distress syndrome, periventricular leukomalacia or necrotizing enterocolitis.

3.2. Mannan-Binding Lectin-Associated Serine Protease-2 (MASP-2) and MBL-MASP-Dependent Complement Activity. MASP-2 has an identical domain organization to other MASPs and the classical complement pathway serine proteases, $\mathrm{C} 1 \mathrm{r}$ and $\mathrm{C} 1 \mathrm{~s}$. It consists of six domains (CUB1, EGF, CUB2, CCP1, CCP2, and a serine protease domain). Several MASP2 gene polymorphisms associated with low protein levels have been described [62-65]. However, only one has been demonstrated to be potentially important clinically: the rarely occurring homozygous C359A > G mutation, resulting in an exchange of aspartic acid for glycine at position 120 (D120G; 105th residue of the mature protein, D105G).
Current knowledge about any disease associations of MASP2 and other proteases of that family, especially in neonates, is much more limited than in the case of MBL.

Swierzko et al. [31] found a correlation between serum MASP-2 concentration and gestational age which accounted for the relationships with early delivery and low birthweight. This observation was further confirmed by Schlapbach et al. [54] and Sallenbach et al. [32]. Neither low MASP-2 concentration nor heterozygosity for the D120G mutation seems to influence the susceptibility of newborns to infection in general [31] or to sepsis [54]. Schlapbach et al. [66] however reported higher MASP-2 levels in the cord sera of babies developing necrotising enterocolitis.

MBL-MASP-dependent lectin pathway complement activity was shown to correlate with birthweight but not gestational age (however, an association between low activity and prematurity was observed) [30].

There are few data concerning other lectin pathway serine proteases. Recently, Schlapbach et al. [54] found a correlation between MASP-3 levels and gestational age as well as birthweight and no impact of its low concentrations on the risk of neonatal sepsis.

3.3. Ficolins. The family of human ficolins comprises three collagen-related, oligomeric lectins: M-ficolin (ficolin-1), Lficolin (ficolin-2, P35), and H-ficolin (ficolin-3, Hakata antigen). They recognize $\mathrm{N}$-acetyl-D-glucosamine (GlcNAc) and related structures via their fibrinogen-like domains. Ficolins act as opsonins (L- and $\mathrm{H}-$ ) or as a phagocytic receptor (Mficolin). All of them activate complement via the lectin pathway $[67,68]$. 
Data concerning $\mathrm{M}$-ficolin in neonates are very limited. Its serum level was shown to increase with gestational age and to reach a maximum during childhood (1-8 years) $[32,69]$. Schlapbach et al. [69] demonstrated that low M-ficolin is associated both with increased need for mechanical ventilation and mortality among premature infants suffering from necrotising enterocolitis. Although the distribution of the corresponding FCN1 gene single-nucleotide polymorphisms (including several leading to amino acid substitutions) has been reported [70, 71], there are no data concerning their importance during the neonatal period.

More than decade ago, Kilpatrick et al. [72] found lower levels of L-ficolin in cord sera compared to adults and a correlation between cord concentration and gestational age. That was further confirmed by Swierzko et al. [30] with a much larger cohort of neonates. In the latter report, a striking association between L-ficolin deficiency and prematurity, low birthweight (independently of gestational age) and perinatal infections was demonstrated. Cord L-ficolin concentration increased markedly throughout the third trimester of pregnancy, reaching a plateau at term. Both premature (at gestational age of $<36$ weeks) and preterm ( $<38$ weeks) births in general occurred more often in babies with low Lficolin concentrations than in the normal L-ficolin group. Mean and median gestational ages were significantly lower while the incidence of low birthweight $(<2500 \mathrm{~g})$ babies was higher. Pre- or perinatal infections occurred with nearly twice the frequency among L-ficolin-deficient babies compar ed to neonates with normal cord serum levels [30]. Further reports $[32,54]$ again confirmed a correlation between L-ficolin concentration and gestational age. No association of this parameter with risk of neonatal sepsis was found [54]. As in the case of FCN1, several potentially clinically important single-nucleotide polymorphisms have been reported [70, $71,73,74]$, however no results about their disease associations from neonates have been published to date.

$\mathrm{H}$-ficolin has the highest concentration in human serum amongst complement-activating lectins. The lowest average value occurs in preterm neonates. Like other ficolins, its serum concentration increases with gestational age $[32,36]$. Both preterm deliveries and low birthweight (independently of gestational age) were shown to be significantly associated with low H-ficolin concentrations [36]. Schlapbach et al. [54] demonstrated an association between low $\mathrm{H}$-ficolin levels and susceptibility to neonatal sepsis (especially caused by Gram-positive bacteria). The same group described two premature patients with necrotising enterocolitis with genetically confirmed (in one case) or assumed (in another) total $\mathrm{H}$-ficolin deficiency [75]. This rare deficiency arises from a homozygous frameshift mutation (1637delC) of the corresponding FCN3 gene [76, 77]. Another H-ficolin-deficient (1637delC homozygote with no detectable protein) premature neonate with confirmed serious infection with Streptococcus agalactiae was described by Michalski et al. [36]. This case, however, was complicated by concomitant deficiencies of other lectin pathway factors (MBL, L-ficolin, MASP-2) as well as variant homozygosity for the TLR6 Ser249Pro dimorphism; thus it is difficult to draw a conclusion whether the lack of active $\mathrm{H}$-ficolin was decisive. Although heterozygosity for the $1637 \mathrm{delC}$ mutation was shown to influence $\mathrm{H}$-ficolin cord serum concentration significantly, no association with prematurity, low birthweight, or perinatal infections occurred [36].

\section{Final Remarks}

Data reviewed here suggest an important role for complement activation via the lectin pathway during the neonatal period. Deficiency of its factors may contribute to the adverse consequences of prematurity by enhancing susceptibility to pre- or perinatal infections. The results published however are not entirely consistent and require further investigation at both gene and protein levels.

\section{Acknowledgments}

This work was partially supported by Polish Ministry of Science and Higher Education, Grants N N402 353438 and N N401 267339. The authors are also grateful to the Royal Society of Edinburgh and Polish Academy of Sciences International Exchange Programme.

\section{References}

[1] A. S. Kemp and D. E. Campbell, "The neonatal immune system," Seminars in Neonatology, vol. 1, no. 2, pp. 67-75, 1996.

[2] A. Stasiak-Barmuta, W. Stankiewicz, M. I. Dabrowski, B. Jurkiewicz, and M. P. Dabrowski, "Distinctions of the neonatal immune system," Central-European Journal of Immunology, vol. 35, no. 4, pp. 252-258, 2010.

[3] A. Sharma, S. Ford, and J. Calvert, "Adaptation for life: a review of neonatal physiology," Anaesthesia \& Intensive Care Medicine, vol. 12, no. 3, pp. 85-90, 2010.

[4] C. A. Siegrist, "The challenges of vaccine responses in early life: selected examples," Journal of Comparative Pathology, vol. 137, supplement 1, pp. S4-S9, 2007.

[5] J. Sonntag, U. Brandenburg, D. Polzehl et al., "Complement system in healthy term newborns: reference values in umbilical cord blood," Pediatric and Developmental Pathology, vol. 1, no. 2, pp. 131-135, 1998.

[6] D. Ricklin, G. Hajishengallis, K. Yang, and J. D. Lambris, "Complement: a key system for immune surveillance and homeostasis," Nature Immunology, vol. 11, no. 9, pp. 785-797, 2010.

[7] U. Amara, M. A. Flierl, D. Rittirsch et al., "Molecular intercommunication between the complement and coagulation systems," Journal of Immunology, vol. 185, no. 9, pp. 56285636, 2010.

[8] C. Ehrnthaller, A. Ignatius, F. Gebhard, and M. Huber-Lang, "New insights of an old defense system: structure, function, and clinical revelance of the complement system," Molecular Medicine, vol. 17, no. 3-4, pp. 317-329, 2011.

[9] M. V. Carroll and R. B. Sim, "Complement in health and disease," Advanced Drug Delivery Reviews, vol. 63, no. 12, pp. 965-975, 2011.

[10] K. Oikonomopoulou, D. Ricklin, P. A. Ward, and J. D. Lambris, "Interactions between coagulation and complementtheir role in inflammation," Seminars in Immunopathology, vol. 34, no. 1, pp. 151-165, 2012. 
[11] K. Madalinski, M. Cedzynski, and A. St. Swierzko, "The lectin pathway of complement activation. The role of complement in pathological processes and possible strategies of its activity modulation in therapy of some diseases," Central-European Journal of Immunology, vol. 28, no. 2, pp. 67-73, 2003.

[12] S. Hansen, L. Selman, N. Palaniyar et al., "Collectin 11 (CL-11, CL-K1) is a MASP-1/3-associated plasma collectin with microbial-binding activity," Journal of Immunology, vol. 185, no. 10, pp. 6096-6104, 2010.

[13] M. Matsushita, "The lectin pathway of the complement system," Microbiology and Immunology, vol. 40, no. 12, pp. 887-893, 1996.

[14] W. Schwaeble, M. R. Dahl, S. Thiel, C. Stover, and J. C. Jensenius, "The mannan-binding lectin-associated serine proteases (MASPs) and MAp19: four components of the lectin pathway activation complex encoded by two genes," Immunobiology, vol. 205, no. 4-5, pp. 455-466, 2002.

[15] S. Thiel and M. Gadjeva, "Humoral pattern recognition molecules: mannan-binding lectin and ficolins," Advances in Experimental Medicine and Biology, vol. 653, pp. 58-73, 2009.

[16] S. E. Degn, A. G. Hansen, R. Steffensen, C. Jacobsen, J. C. Jensenius, and S. Thiel, "MAp44, a human protein associated with pattern recognition molecules of the complement system and regulating the lectin pathway of complement activation," Journal of Immunology, vol. 183, no. 11, pp. 7371-7378, 2009.

[17] M. O. Skjoedt, T. Hummelshoj, Y. Palarasah et al., "A novel mannose-binding lectin/ficolin-associated protein is highly expressed in heart and skeletal muscle tissues and inhibits complement activation," Journal of Biological Chemistry, vol. 285, no. 11, pp. 8234-8243, 2010.

[18] T. Yongqing, N. Dretin, R. D. Duncan, L. C. Wijeyewickrema, and R. N. Pike, "Mannose-binding lectin serine proteases and associated proteins of the lectin pathway of complement: two genes, five proteins and many functions?" Biochimica et Biophysica Acta, vol. 1824, no. 1, pp. 253-262, 2012.

[19] M. Matsushita, S. Thiel, J. C. Jensenius, I. Terai, and T. Fujita, "Proteolytic activities of two types of mannose-binding lectin-associated serine protease," Journal of Immunology, vol. 165, no. 5, pp. 2637-2642, 2000.

[20] V. Rossi, S. Cseh, I. Bally, N. M. Thielens, J. C. Jensenius, and G. J. Arlaud, "Substrate specificities of recombinant mannanbinding lectin-associated serine proteases-1 and -2," Journal of Biological Chemistry, vol. 276, no. 44, pp. 40880-40887, 2001.

[21] K. Hajela, M. Kojima, G. Ambrus et al., "The biological functions of MBL-associated serine proteases (MASPs)," Immunobiology, vol. 205, no. 4-5, pp. 467-475, 2002.

[22] M. Moller-Kristensen, S. Thiel, A. Sjoholm, M. Matsushita, and J. C. Jensenius, "Cooperation between MASP-1 and MASP-2 in the generation of C3 convertase through the MBL pathway," International Immunology, vol. 19, no. 2, pp. 141-149, 2007.

[23] A. Kocsis, K. A. Kekesi, R. Szasz et al., "Selective inhibition of the lectin pathway complement with phage display selected peptides against mannose-binding lectin-associated serine protease (MASP)-1 and -2: significant contribution of MASP1 to lectin pathway activation," Journal of Immunology, vol. 185, no. 7, pp. 4169-4178, 2010.

[24] M. O. Skjoedt, T. Hummelshoj, Y. Palarasah et al., "Serum concentration and interaction properties of $\mathrm{MBL} /$ ficolin associated protein-1," Immunobiology, vol. 216, no. 5, pp. 625-632, 2011.

[25] R. Wallis, "Structural and functional aspects of complement activation by mannose-binding protein," Immunobiology, vol. 205, no. 4-5, pp. 433-445, 2002.
[26] A. St. Swierzko, M. Cedzynski, T. Kirikae et al., "Role of the complement-lectin pathway in anaphylactoid reaction induced with lipopolysaccharide in mice," European Journal of Immunology, vol. 33, no. 10, pp. 2842-2852, 2003.

[27] A. Krarup, R. Wallis, J. S. Presanis, P. Gál, and R. B. Sim, "Simultaneous activation of complement and coagulation by MBL-associated serine protease 2," PLoS ONE, vol. 2, no. 7, article e623, 2007.

[28] J. Dobo, V. Harmat, L. Beinrohr, E. Sebestyen, P. Zavodszky, and P. Gál, "MASP-1, a promiscuous complement protease: structure of its catalytic region reveals the basis of its broad specificity," Journal of Immunology, vol. 183, no. 2, pp. 1207-1214, 2009.

[29] K. C. Gulla, K. Gupta, A. Krarup et al., "Activation of mannanbinding lectin-associated serine proteases leads to generation of a fibrin clot," Immunology, vol. 129, no. 4, pp. 482-495, 2010.

[30] A. St. Swierzko, A. P. M. Atkinson, M. Cedzynski et al., "Two factors of the lectin pathway of complement, L-ficolin and mannan-binding lectin, and their associations with prematurity, low birthweight and infections in a large cohort of Polish neonates," Molecular Immunology, vol. 46, no. 4, pp. 551-558, 2009.

[31] A. St. Swierzko, M. Cedzynski, I. Domzalska-Popadiuk et al., "Mannan-binding lectin-associated serine protease-2 (MASP2 ) in a large cohort of neonates and its clinical associations," Molecular Immunology, vol. 46, no. 8-9, pp. 1696-1701, 2009.

[32] S. Sallenbach, S. Thiel, C. Aebi et al., "Serum concentrations of lectin-pathway components in healthy neonates, children and adults: mannan-binding lectin (MBL), M-, L-, and $\mathrm{H}$-ficolin, and MBL-associated serine protease-2 (MASP-2)," Pediatric Allergy and Immunology, vol. 22, no. 4, pp. 424-430, 2011.

[33] D. C. Kilpatrick, "Clinical significance of mannan-binding lectin and L-ficolin," in Collagen-Related Lectins in Innate Immunity, D. Kilpatrick, Ed., pp. 57-84, Research Signpost, Trivandrum, India, 2007.

[34] S. Thiel, "Complement activating soluble pattern recognition molecules with collagen-like regions, mannan-binding lectin, ficolins and associated proteins," Molecular Immunology, vol. 44, no. 16, pp. 3875-3888, 2007.

[35] A. St. Swierzko, A. Szala, M. Cedzynski et al., "Mannanbinding lectin genotypes and genotype-phenotype relationships in a large cohort of Polish neonates," Human Immuno$\log y$, vol. 70, no. 1, pp. 68-72, 2009.

[36] M. Michalski, A. Szala, A. St. Swierzko et al., "H-ficolin (ficolin-3) concentrations and FCN3 gene polymorphism in neonates," Immunobiology. In press.

[37] H. O. Madsen, P. Garred, S. Thiel et al., "Interplay between promoter and structural gene variants control basal serum level of mannan-binding protein," Journal of Immunology, vol. 155, no. 6, pp. 3013-3020, 1995.

[38] R. Wallis and N. J. Lynch, "Biochemistry and genetics of the collectins," in Collagen-Related Lectins in Innate Immunity, D. Kilpatrick, Ed., pp. 195-202, Research Signpost, Trivandrum, India, 2007.

[39] Y. L. Lau, S. Y. Chan, M. W. Turner, J. Fong, and J. Karlberg, "Mannose-binding protein in preterm infants: developmental profile and clinical significance," Clinical and Experimental Immunology, vol. 102, no. 3, pp. 649-654, 1995.

[40] S. Kielgast, S. Thiel, T. B. Henriksen, T. Bjerke, J. Olsent, and J. C. Jensenius, "Umbilical cord mannan-binding lectin and infections in early childhood," Scandinavian Journal of Immunology, vol. 57, no. 2, pp. 167-172, 2003. 
[41] A. Hilgendorff, R. Schmidt, A. Bohnert, C. Merz, G. Bein, and L. Gortner, "Host defence lectins in preterm neonates," Acta Paediatrica, vol. 94, no. 6, pp. 794-799, 2005.

[42] O. A. Bodamer, G. Mitterer, W. Maurer, A. Pollak, M. W. Mueller, and W. M. Schmidt, "Evidence for an association between mannose-binding lectin 2 (MBL2) gene polymorphisms and pre-term birth," Genetics in Medicine, vol. 8, no. 8, pp. 518-524, 2006

[43] F. N. J. Frakking, N. Brouwer, D. Zweers et al., "High prevalence of mannose-binding lectin (MBL) deficiency in premature neonates," Clinical and Experimental Immunology, vol. 145, no. 1, pp. 5-12, 2006.

[44] M. F. Annells, P. H. Hart, C. G. Mullighan et al., "Interleukins$1,-4,-6,-10$, tumor necrosis factor, transforming growth factor- $\beta$, FAS, and mannose-binding protein $\mathrm{C}$ gene polymorphisms in Australian women: risk of preterm birth," American Journal of Obstetrics and Gynecology, vol. 191, no. 6, pp. 2056-2067, 2004.

[45] F. E. van de Geijn, A. Roos, Y. A. de Man et al., "Mannosebinding lectin levels during pregnancy: a longitudinal study," Human Reproduction, vol. 22, no. 2, pp. 362-371, 2007.

[46] F. N. J. Frakking, N. Brouwer, N. K. A. van Eijkelenburg et al., "Low mannose-binding lectin (MBL) levels in neonates with pneumonia and sepsis," Clinical and Experimental Immuno$\log y$, vol. 150, no. 2, pp. 255-262, 2007.

[47] F. de Benedetti, C. Auriti, L. E. D’Urbano et al., "Low serum levels of mannose binding lectin are a risk factor for neonatal sepsis," Pediatric Research, vol. 61, no. 3, pp. 325-328, 2007.

[48] A. B. Dzwonek, O. W. Neth, R. Thilbaut et al., "The role of mannose-binding lectin in susceptibility to infection in preterm neonates," Pediatric Research, vol. 63, no. 6, pp. 680-685, 2008.

[49] C. Auriti, G. Prencipe, R. Inglese et al., "Role of mannosebinding lectin in nosocomial sepsis in critically ill neonates," Human Immunology, vol. 71, no. 11, pp. 1084-1088, 2010.

[50] O. A. Koroglu, H. Onay, G. Erdemir et al., "Mannose-binding lectin gene polymorphism and early neonatal outcome in preterm infants," Neonatology, vol. 98, no. 4, pp. 305-312, 2010.

[51] O. Ozdemir, E. C. Dinleyici, N. Tekin, O. Colak, and M. A. Aksit, "Low-mannose-binding lectin levels in susceptibility to neonatal sepsis in preterm neonates with fetal inflammatory response syndrome," Journal of Maternal-Fetal and Neonatal Medicine, vol. 23, no. 9, pp. 1009-1013, 2010.

[52] W. A. Wahab Mohamed and M. A. Saeed, "Mannose-binding lectin serum levels in neonatal sepsis and septic shock," Journal of Maternal-Fetal and Neonatal Medicine, vol. 25, no. 4, pp. 411-414, 2012.

[53] H. Özkan, N. Köksal, M. Çetinkaya et al., "Serum mannosebinding lectin (MBL) gene polymorphism and low MBL levels are associated with neonatal sepsis and pneumonia," Journal of Perinatology, vol. 32, no. 3, pp. 210-217, 2012.

[54] L. J. Schlapbach, M. Mattmann, S. Thiel et al., "Differential role of the lectin pathway of complement activation in susceptibility to neonatal sepsis," Clinical Infectious Diseases, vol. 51, no. 2, pp. 153-162, 2010.

[55] C. S. Gibson, A. H. MacLennan, P. N. Goldwater, E. A. Haan, K. Priest, and G. A. Dekker, "Mannose-binding lectin haplotypes may be associated with cerebral palsy only after perinatal viral exposure," American Journal of Obstetrics and Gynecology, vol. 198, no. 5, pp. 509.e1-509.e8, 2008.

[56] C. Aydemir, H. Onay, S. S. Oguz et al., "Mannose-binding lectin codon 54 gene polymorphism in relation to risk of nosocomial invasive fungal infection in preterm neonates in the neonatal intensive care unit," Journal of Maternal-Fetal and Neonatal Medicine, vol. 24, no. 9, pp. 1124-1127, 2011.

[57] W. C. van der Zwet, A. Catsburg, R. M. van Elburg, P. H. M. Savelkoul, and C. M. J. E. Vandenbroucke-Grauls, "Mannosebinding lectin (MBL) genotype in relation to risk of nosocomial infection in pre-term neonates in the neonatal intensive care unit," Clinical Microbiology and Infection, vol. 14, no. 2, pp. 130-135, 2008.

[58] P. Ahrens, E. Kattner, B. Kohler et al., "Mutations of genes involved in the innate immune system as predictors of sepsis in very low birth weight infants," Pediatric Research, vol. 55, no. 4, pp. 652-656, 2004.

[59] A. Szala, E. Paradowska, D. Nowakowska et al., "Mannanbinding lectin-2 (MBL2) gene polymorphisms in prenatal and perinatal cytomegalovirus infections," Molecular Immunology, vol. 48, no. 15-16, pp. 2203-2206, 2011.

[60] A. Hilgendorff, K. Heidinger, A. Pfeiffer et al., "Association of polymorphisms in the mannose-binding lectin gene and pulmonary morbidity in preterm infants," Genes and Immunity, vol. 8, no. 8, pp. 671-677, 2007.

[61] E. Capoluongo, G. Vento, S. Rocchetti et al., "Mannose-binding lectin polymorphisms and pulmonary outcome in premature neonates: a pilot study," Intensive Care Medicine, vol. 33, no. 10, pp. 1787-1794, 2007.

[62] K. Stengaard-Pedersen, S. Thiel, M. Gadjeva et al., "Inherited deficiency of mannan-binding lectin-associated serine protease 2," New England Journal of Medicine, vol. 349, no. 6, pp. 554-560, 2003.

[63] S. Thiel, R. Steffensen, I. J. Christensen et al., "Deficiency of mannan-binding lectin associated serine protease- 2 due to missense polymorphisms," Genes and Immunity, vol. 8, no. 2, pp. 154-163, 2007.

[64] M. I. Garcia-Laorden, J. Sole-Violan, F. R. de Castro et al., "Mannose-binding lectin and mannose-binding lectinassociated serine protease 2 in susceptibility, severity, and outcome of pneumonia in adults," Journal of Allergy and Clinical Immunology, vol. 122, no. 2, pp. 368.e2-374.e2, 2008.

[65] A. B. W. Boldt, C. Grisbach, R. Steffensen et al., "Multiplex sequence-specific polymerase chain reaction reveals new MASP2 haplotypes associated with MASP-2 and MAp19 serum levels," Human Immunology, vol. 72, no. 9, pp. 753-760, 2011.

[66] L. J. Schlapbach, C. Aebi, U. Fisch et al., "Higher cord blood levels of mannose-binding lectin-associated serine protease-2 in infants with necrotising enterocolitis," Pediatric Research, vol. 64 , no. 5, pp. 562-566, 2008.

[67] M. Matsushita, "Ficolins: complement-activating lectins involved in innate immunity," Journal of Innate Immunity, vol. 2, no. 1, pp. 24-32, 2010.

[68] Y. Endo, M. Matsushita, and T. Fujita, "The role of ficolins in the lectin pathway of innate immunity," International Journal of Biochemistry and Cell Biology, vol. 43, no. 5, pp. 705-712, 2011.

[69] L. J. Schlapbach, U. Kessler, S. Thiel et al., "M-ficolin in the neonatal period: associations with need for mechanical ventilation and mortality in premature infants with necrotising enterocolitis," Molecular Immunology, vol. 46, no. 13, pp. 2597-2603, 2009.

[70] T. Hummelshoj, L. Munthe-Fog, H. O. Madsen, and P. Garred, "Functional SNPs in the human ficolin $(F C N)$ genes reveal distinct geographical patterns," Molecular Immunology, vol. 45, no. 9, pp. 2508-2520, 2008. 
[71] P. Garred, C. Honore, Y. J. Ma et al., "The genetics of ficolins," Journal of Innate Immunity, vol. 2, no. 1, pp. 3-16, 2009.

[72] D. C. Kilpatrick, T. Fujita, and M. Matsushita, "P35, an opsonic lectin of the ficolin family, in human blood from neonates, normal adults, and recurrent miscarriage patients," Immunology Letters, vol. 67, no. 2, pp. 109-112, 1999.

[73] L. Munthe-Fog, T. Hummelshoj, B. E. Hansen et al., "The impact of FCN2 polymorphisms and haplotypes on the Ficolin-2 serum levels," Scandinavian Journal of Immunology, vol. 65, no. 4, pp. 383-392, 2007.

[74] M. Cedzynski, L. Nuytinck, A. P. M. Atkinson et al., "Extremes of L-ficolin concentration in children with recurrent infections are associated with single nucleotide polymorphisms in the FCN2 gene," Clinical and Experimental Immunology, vol. 150, no. 1, pp. 99-104, 2007.

[75] L. J. Schlapbach, S. Thiel, U. Kessler, R. A. Ammann, C. Aebi, and J. C. Jensenius, "Congenital H-ficolin deficiency in premature infants with severe necrotising enterocolitis," Gut, vol. 60, no. 10, pp. 1438-1439, 2011.

[76] L. Munthe-Fog, T. Hummelshoj, C. Honore, H. O. Madsen, H. Permin, and P. Garred, "Immunodeficiency associated with FCN3 mutation and ficolin-3 deficiency," New England Journal of Medicine, vol. 360, no. 25, pp. 2637-2644, 2009.

[77] L. Munthe-Fog, T. Hummelshoj, Y. J. Ma et al., "Characterization of a polymorphism in the coding sequence of FCN3 resulting in ficolin-3 (Hakata antigen) deficiency state," Molecular Immunology, vol. 45, no. 9, pp. 2660-2666, 2008. 

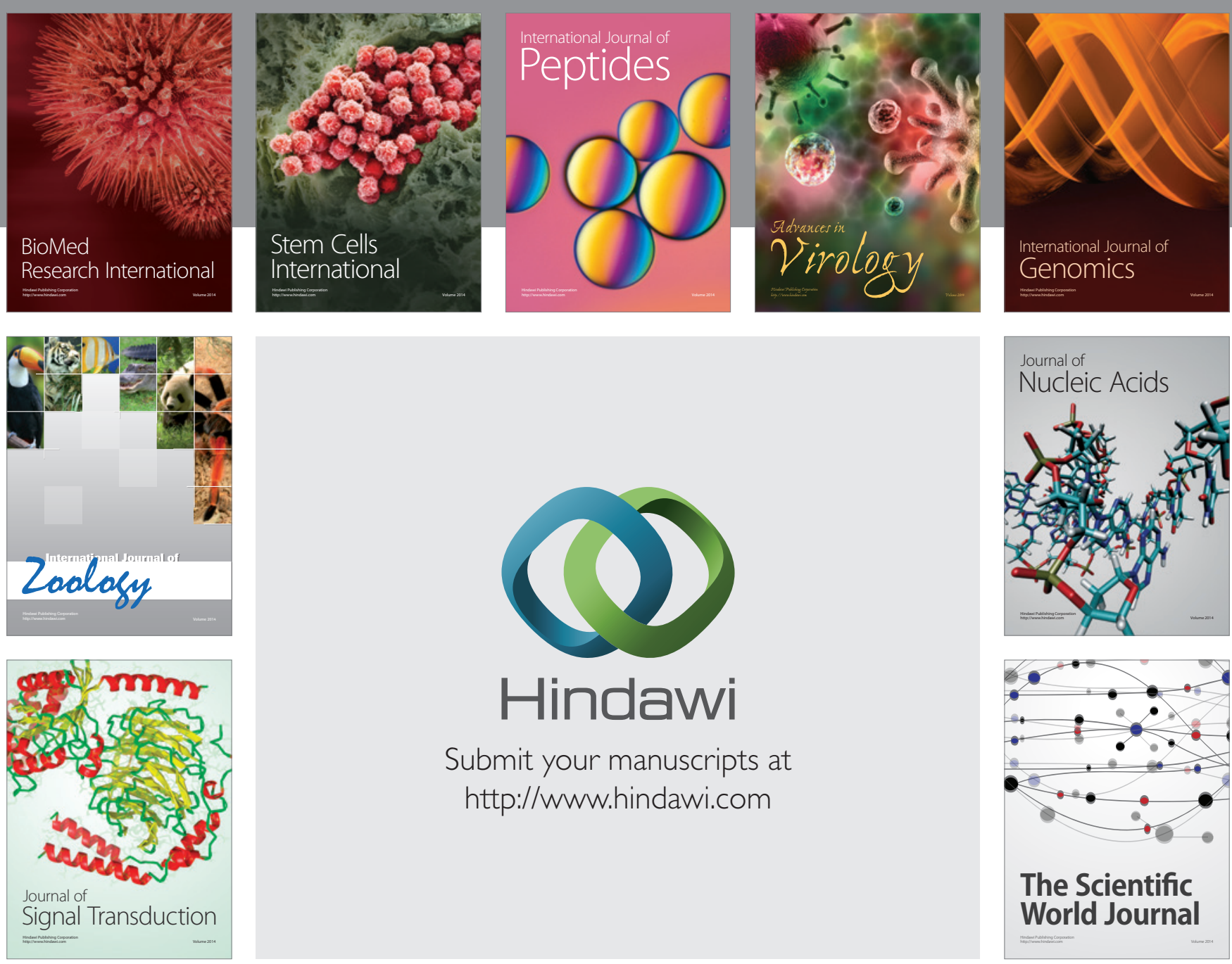

Submit your manuscripts at

http://www.hindawi.com
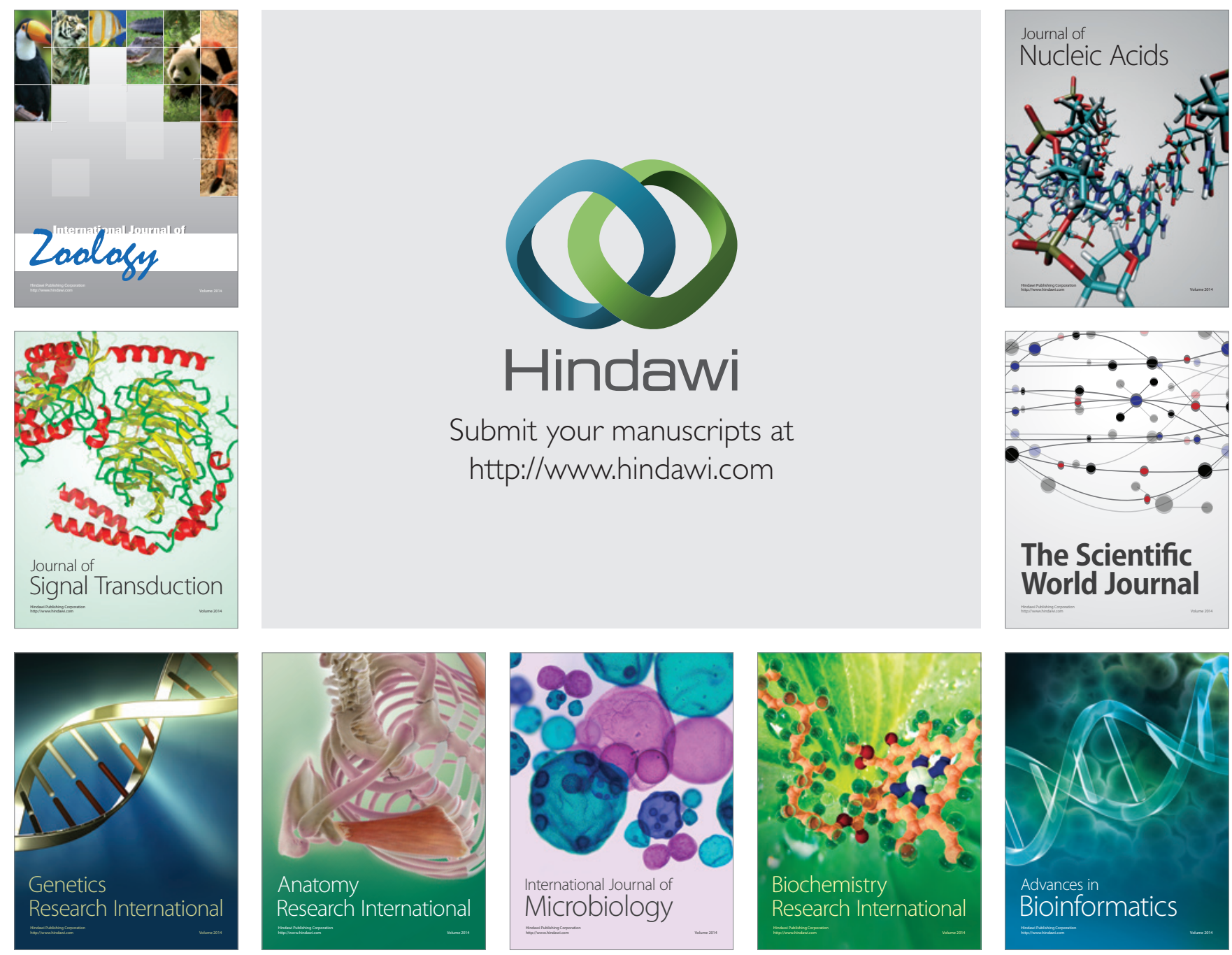

The Scientific World Journal
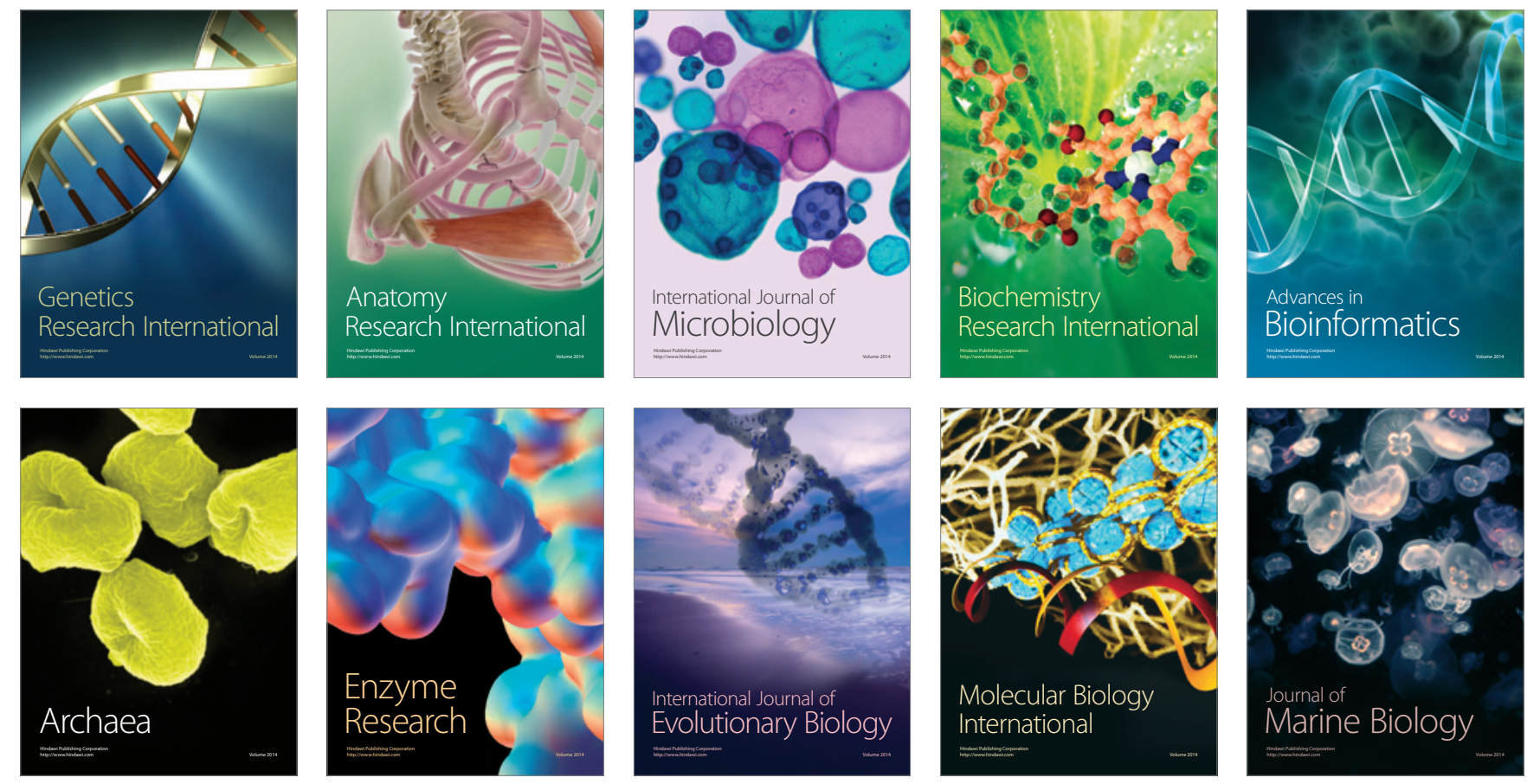